\title{
New and little known species of Plateros Bourgeois, 1879 (Coleoptera: Lycidae) from Sundaland
}

\author{
Новые и малоизвестные виды Plateros Bourgeois, 1879 \\ (Coleoptera: Lycidae) из Сундаланда
}

\author{
Sergey V. Kazantsev \\ С.В.Казанцев
}

Insect Centre, Donetskaya 13-326, Moscow 109651, Russia

Инсект-центр, ул. Донецкая 13-326, Москва, 109651, Россия, е-mail: kazantss@mail.ru

KEY WORDS: Coleoptera, Lycidae, Platerotini, Plateros, new species, Oriental region (Sundaland), synonymy, lectotypes.

КЛЮЧЕВЫЕ СЛОВА: Coleoptera, Lycidae, Platerotini, Plateros, новые виды, Ориентальная область (Сундаланд), синонимия, лектотипы.

ABSTRACT. Fifteen new lycid species from Malaysia and Indonesia are described in the genus Plateros: $P$. alabensis, $P$. benomensis, $P$. brinchangensis, $P$. chechovskyi, P. frasericollis, P. guamasangensis, P. hastatus, P. khvylyai, P. kurbatovorum, P. lampungensis, P. laruticollis, $P$. pandrakensis, $P$. riauensis, $P$. selendangensis and P. sundaensis spp.n. Plateros soror (Kleine, 1930), syn.n. is synonymized with $P$. irregularis (Pic, 1921) and $P$. nigricolor Pic, 1943, syn.n. and P. pullatus Kazantsev, 2011, syn.n. are synonymized with $P$. vetustus Kleine, 1932. Lectotypes are designated for thirteen Sundaland taxa: Plateros alternatus Pic, 1921, P. bicoloripes Pic, 1943, P. malaccanus Pic, 1928, P. nigricolor Pic, 1943, Melampyrus angustatus Pic, 1926, M. sirambeus Pic, 1921, Ditoneces atripennis Pic, 1921, D. aurantiacus Pic, 1926, D. irregularis Pic, 1926, D. maculatipes Pic, 1926, D. suturalis Pic, 1925, Microditoneces manaensis Pic, 1921, M. nigrosuturalis Pic, 1921.

РЕЗЮМЕ. Из Малайзии и Индонезии описывается пятнадцать новых видов краснокрылов рода Plateros: $P$. alabensis, $P$. benomensis, $P$. brinchangensis, $P$. chechovskyi, $P$. frasericollis, $P$. guamasangensis, $P$. hastatus, P. khvylyai, P. kurbatovorum, P. lampungensis, $P$. laruticollis, $P$. pandrakensis, $P$. riauensis, $P$. selendangensis и P. sundaensis spp.n. Plateros soror (Kleine, 1930), syn.n. сводится в синонимы к $P$. irregularis (Pic, 1921), a P. nigricolor Pic, 1943, syn.n. и P. pullatus Kazantsev, 2011, syn.n. сводятся в синонимы к $P$. vetustus Kleine, 1932. Обозначаются лектотипы для тринадцати сундаландских таксонов: Plateros alternatus Pic, 1921, P. bicoloripes Pic, 1943, P. malaccanus Pic, 1928, P. nigricolor Pic, 1943, Melampyrus angustatus Pic, 1926, M. sirambeus Pic, 1921, Ditoneces atripennis Pic, 1921, D. aurantiacus Pic, 1926, D. irregularis Pic, 1926, D. maculatipes Pic, 1926, D. suturalis Pic, 1925, Microditoneces manaensis Pic, 1921, M. nigrosuturalis Pic, 1921.

\section{Introduction}

Plateros Bourgeois, 1879 is one of the most speciesrich lycid genera, with almost world-wide distribution. It is absent only in the western Palaearctic, the Greater Antilles, Madagascar, New Zealand and Melanesia/ Polynesia. A number of papers dealing with the Plateros fauna of various regions were published recently [e.g., Bocáková, 1997a, b; Zaragoza, 1999; Kazantsev, 1991, 1992, 1997, 2000, 2001, 2005, 2011, etc.], bringing the number of species described in this genus to over 800. Despite this, almost every new entomological expedition to primary forests in tropical countries brings more new forms. Descriptions of some of these new taxa collected in the Malay Peninsula and the islands of Borneo, Java and Sumatra, as well as certain synonymic notes are presented below. Lectotypes are designated for thirteen Sundaland Plateros species, eleven of them illustrated.

The following acronyms are used in the paper: ICCM - Insect Center Collection, Moscow;

MNHN - Muséum national d'Histoire naturelle, Paris.

\section{Taxonomy}

Plateros alternus Kazantsev, 2005

Figs 1-3

Plateros alternus Kazantsev, 2005: 244, replacement name

Plateros alternatus (Pic, 1921): 4 (Ditoneces), nec Plateros alternatus Bourgeois, 1899: 663

MATERIAL: Lectotype, hereby designated, $\sigma^{7}$, [Sumatra], «Lau Rakit, II.1918, Corporaal» [Corporaal's manuscript label], «D. alternatus n.sp." [Pic's manuscript label] (MNHN).

REMARKS. As Pic's [1921] description does not indicate the uniqueness of the specimen, the lectotype of $\mathrm{Di}$ toneces alternatus Pic, 1921 is hereby designated in compliance with the ICZN to clarify the application of the name to a taxon. 
Plateros angustatus (Pic, 1926)

Figs 4-5

Melampyrus angustatus Pic, 1926: 23

MATERIAL: Lectotype, hereby designated, $\sigma^{7}$, "Sumatra's O. K., Lau Rakit, 300 m, 29.VIII.1921, J.B. Corporaal" [printed], "Melampyrus angustatus n.sp." [Pic's manuscript label] (MNHN).

REMARKS. As Pic's [1926] description does not indicate the uniqueness of the specimen, the lectotype of Melampyrus angustatus Pic, 1926 is hereby designated in compliance with the ICZN to clarify the application of the name to a taxon.

Plateros atripennis (Pic, 1921)

Figs 6-7

Ditoneces atripennis Pic, 1921: 4

MATERIAL: Lectotype, hereby designated, $\sigma^{7}$, [Sumatra], "Bosehres Bandas, 12.II.1920, J.B. Corporaal" [Corporaal's manuscript label], "No. 3", “D. atripennis n.sp." [Pic's manuscript label] (MNHN).

REMARKS. As Pic's [1921] description does not indicate the uniqueness of the specimen, the lectotype of $\mathrm{Di}$ toneces atripennis Pic, 1921 is hereby designated in compliance with the ICZN to clarify the application of the name to a taxon.
Plateros aurantiacus (Pic, 1926)

Figs 8-9

Ditoneces aurantiacus Pic, 1926: 24

MATERIAL: Lectotype, hereby designated, $\sigma^{7}$, [Sumatra], "Medan, 23.III.1910, J.B. Corporaal" [Corporaal's manuscript label], "No. 13", "rufescens W. probabl.", "Ditoneces aurantiacus n.sp." [Pic's manuscript labels] (MNHN).

REMARKS. As Pic's [1926] description does not indicate the uniqueness of the specimen, the lectotype of Ditoneces aurantiacus Pic, 1926 is hereby designated in compliance with the ICZN to clarify the application of the name to a taxon.

Plateros bicoloricrus Kazantsev, 2011 Figs 10-11

Plateros bicoloricrus Kazantsev, 2011: 185, replacement name

Plateros bicoloripes Pic, 1943: 14, nec Plateros bicoloripes Pic, 1923: 3

MATERIAL: Lectotype, hereby designated, $\sigma^{\top}$, «Borneo, Sandakan », «bicoloripes n.sp." [Pic's manuscript labels] (MNHN).

REMARKS. As Pic's [1943] description does not indicate the uniqueness of the specimen, the lectotype of Plateros bicoloripes Pic, 1943 is hereby designated in compliance with the ICZN to clarify the application of the name to a taxon. Only abdomen with the aedeagus is left of the Lectotype.

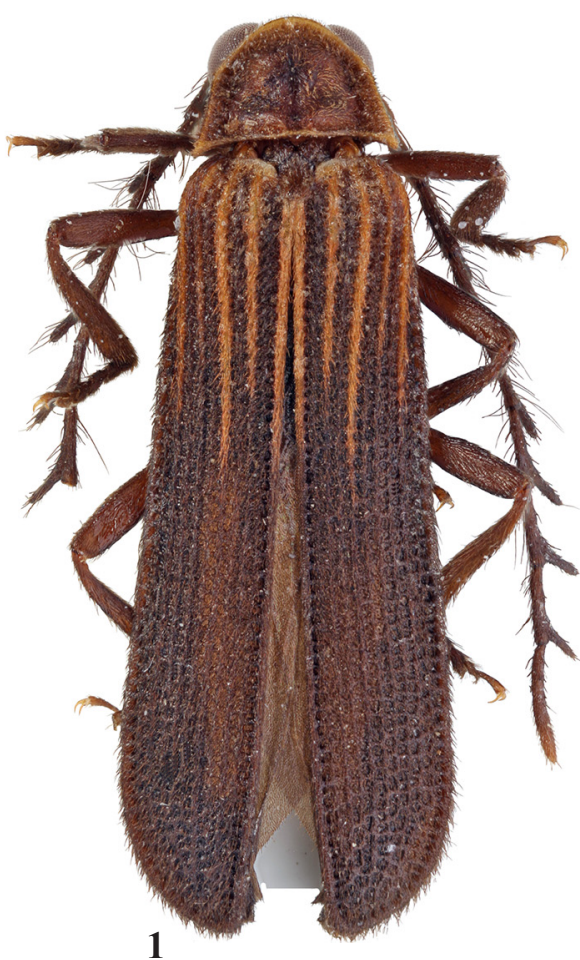

1

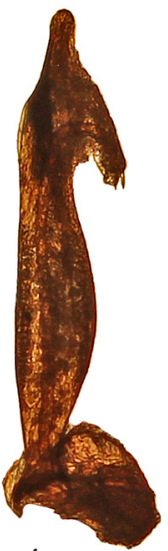

4

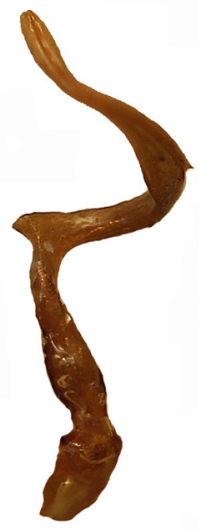

2
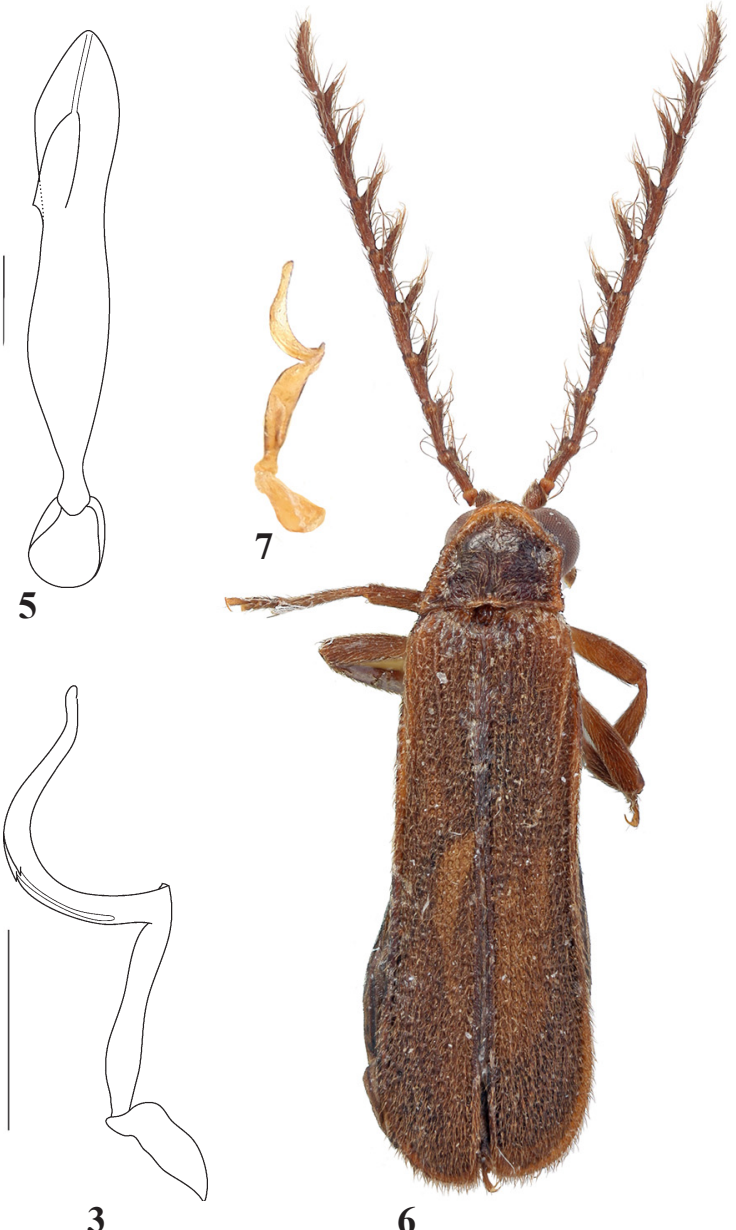

Figs 1-7. General view and aedeagus of Plateros spp., lectotype males: 1-3 - P. alternus, 4-5 - P. angustatus, 6-7 - P. atripennis; 1, 6 - general view; $2-5,7$ - aedeagus; $1,5-6$ - dorsally; 2 - ventrally; $3-4,7$ - laterally. Scale: $0.5 \mathrm{~mm}$.

Рис. 1-7. Общий вид и эдеагус Plateros, лектотипы, самцы: 1-3 - P. alternus, 4-5 - P. angustatus, 6-7 - P. atripennis; 1, 6 общий вид; 2-5, 7 - эдеагус; 1, 5-6 - сверху; 2- снизу; 3-4, 7 - сбоку. Масштабная линейка: 0.5 мм. 
Plateros maculatipes (Pic, 1926)

Figs 12-14

Ditoneces maculatipes Pic, 1926: 33

MATERIAL: Lectotype, hereby designated, O", "Sumatra's O. K., Lau Rakit, 300 m, II.1918, J.B. Corporaal” [printed], “Ditoneces maculatipes n.sp." [Pic's manuscript label] (MNHN).

REMARKS. As Pic's [1926] description does not indicate the uniqueness of the specimen, the lectotype of Ditoneces maculatipes (Pic, 1926) is hereby designated in compliance with the ICZN to clarify the application of the name to a taxon.

\section{Plateros manaensis (Pic, 1921)}

Figs 15-16

Microditoneces manaensis Pic, 1921: 5

MATERIAL: Lectotype, hereby designated, ơ, [Sumatra], "Mana-Riang, Ranau, Palembang, 2-3000', IV.[18]90, T.Z. Kannegieter" [printed], "Microditoneces", "manaensis n.sp.”[Pic's manuscript labels] (MNHN).

REMARKS. As Pic's [1921] description does not indicate the uniqueness of the specimen, the lectotype of Microditoneces manaensis Pic, 1921 is hereby designated in compliance with the ICZN to clarify the application of the name to a taxon.
Plateros nigrosuturalis (Pic, 1921)

Figs 17-18

Microditoneces nigrosuturalis Pic, 1921: 5

MATERIAL: Lectotype, hereby designated, ơ, [Sumatra], "Mana-Riang, Ranau, Palembang, 2-3000', IV.[18]90, T.Z. Kannegieter" [printed], "O'", "Microditoneces", "nigrosuturalis n.sp." [Pic's manuscript labels] (MNHN).

REMARKS. As Pic's [1921] description does not indicate the uniqueness of the specimen, the lectotype of Microditoneces nigrosuturalis Pic, 1921 is hereby designated in compliance with the ICZN to clarify the application of the name to a taxon.

\section{Plateros semang Kazantsev, 2011}

Figs 19-20

Plateros semang Kazantsev, 2011: 186, replacement name

Plateros malaccanus (Pic, 1928): 15 (Ditoneces), nec Plateros malaccanus (Pic, 1921): 3 (Cautirodes)

MATERIAL: Lectotype, hereby designated, or, [Malaysia], "Perak (Doherty)", "Ditoneces", "Ditoneces malaccanus Pic" [Pic's manuscript labels] (MNHN); O', [Malaysia], Selangor, KL, Ampang, 1.I.1964, J.R.P.; O', W Sumatra, 23 km S Padang, 60 m,

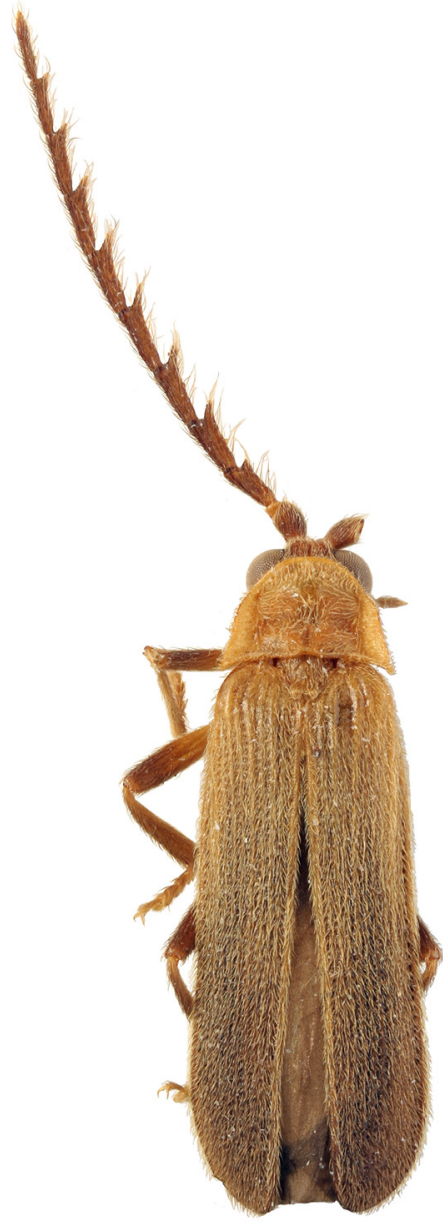

12
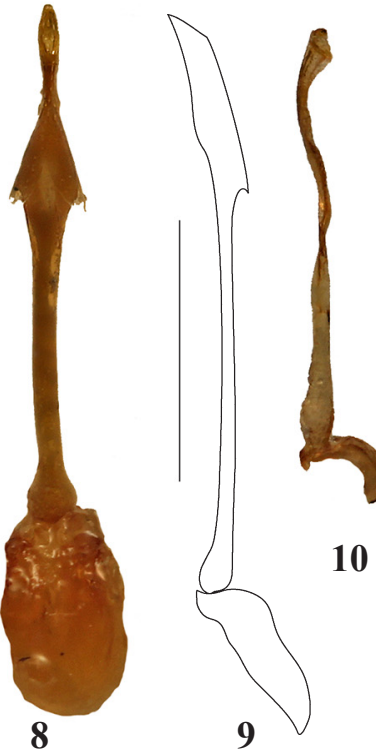

10

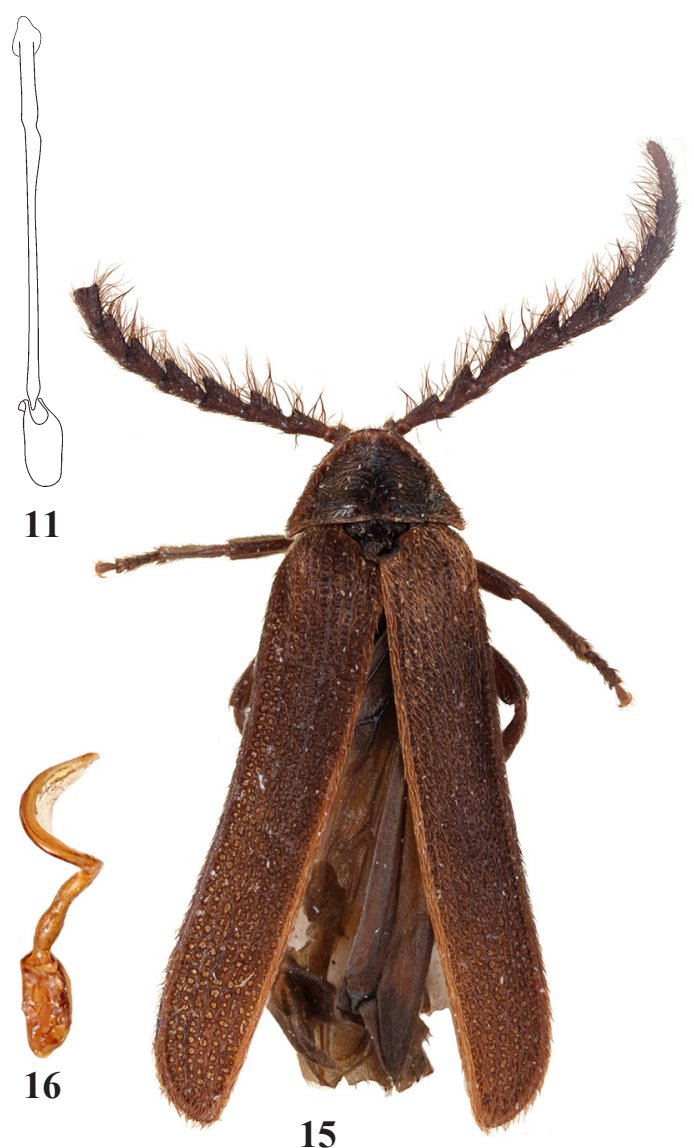

Figs 8-16. General view and aedeagus of Plateros spp., lectotype males: 8-9 - P. aurantiacus, 10-11 - P. bicoloricrus, 12-14 - P. maculatipes, 15-16 - P. manaensis; 12, 15 - general view; 8-11, 13-14, 16 - aedeagus; 8, 11, 12-13, 16 - dorsally; 9, 14 - laterally. Scale: $0.5 \mathrm{~mm}$.

Рис. 8-16. Общий вид и эдеагус Plateros, лектотипы, самцы: 8-9 - P. aurantiacus, 10-11 - P. bicoloricrus, 12-14 - P. maculatipes, 15-16 - P. manaensis; 12, 15 - общий вид; 8-11, 13-14, 16 - эдеагус; 8, 11, 12-13, 16 - сверху; 9, 14 - сбоку. Масштабная линейка: 0.5 мм. 
$01^{\circ} 08.8^{\prime} \mathrm{N} 100^{\circ} 23.31^{\prime} \mathrm{E}, 25-26 . \mathrm{I} .2013$, O. Gorbunov leg. (ICCM). REMARKS. As Pic's [1928] description does not indicate the uniqueness of the specimen, the lectotype of Ditoneces malaccanus Pic, 1928 is hereby designated in compliance with the ICZN to clarify the application of the name to a taxon.

\section{Plateros sirambeus (Pic, 1921)}

Fig. 21

Melampyris sirambeus Pic, 1921: 5

MATERIAL: Lectotype, hereby designated, + , "Sumatra, SiRambe, XII.1890-III.1891, E. Modigliani” [printed] " 231 " [printed], "type" [Pic's manuscript label], "Type" [printed on red rectangle], "sirambeus n.sp." [Pic's manuscript label] (MNHN).

REMARKS. As Pic's [1921] description does not indicate the uniqueness of the specimen, the lectotype of Melampyris sirambeus Pic, 1921 is hereby designated in compliance with the ICZN to clarify the application of the name to a taxon.

Plateros suturellus Kazantsev, 2005

Figs 22-23

Plateros suturellus Kazantsev, 2005: 244, replacement name Plateros suturalis (Pic, 1925): 10 (Ditoneces), nec Plateros suturalis Pic, 1919: 21

MATERIAL: Lectotype, hereby designated, $\sigma^{7}$, "Sumatra's O. K., Medan, 20 m, 1.VIII.1921, J.B. Corporaal" [printed], "Ditoneces suturalis n.sp." [Pic's manuscript label] (MNHN).

REMARKS. As Pic's [1925] description does not indicate the uniqueness of the specimen, the lectotype of Ditoneces suturalus Pic, 1925 is hereby designated in compliance with the ICZN to clarify the application of the name to a taxon.

\section{Plateros alabensis Kazantsev sp.n.}

Figs 24-25

MATERIAL: Holotype, $0^{7}$, E Malaysia, Sabah, Banjaran Crocker Mts., Gunung Alab peak, 1650-1800 m, 30.IV-27.V.1996, M. Strba \& R. Hergovits leg. (ICCM); paratypes, 3 ㅇ, same label (ICCM).

DESCRIPTION. Male. Black; elytra, except at humeri and apices, ochre.

Head dorsally flat, with minute impression behind antennal prominence, antennal sockets almost contiguous. Eyes large (separated medially above by about 0.6 times their diameter). Ultimate maxillary palpomere only slightly longer than wide, parallel-sided, flattened and obliquely truncate at apex. Antennae from antennomere 3 flabellate, extending to elytral two thirds; flabellae long and narrow, flabellum of antennomere 5 ca. 2.6 times longer than antennomere; antennomere 3 about 3.4 times longer than antennomere 2 and subequal in length to antennomere 4; pubescence sparse, long and erect (Fig. 24).

Pronotum transverse, 1.4 times wider than long, trapezoidal, with noticeable anterior and acute posterior angles; anterior margin triangularly produced forward, posterior margin conspicuously bisinuate. Scutellum trapezoidal, slightly narrowing distally, truncate at apex (Fig. 24).

Elytra long (3.75 times as long as wide humerally), slightly widened distally, with equally developed primary costae, hardly distinguishable from secondary ones; interstices with small quadrate cells. Pubescence uniform, short, dense and decumbent (Fig. 24).

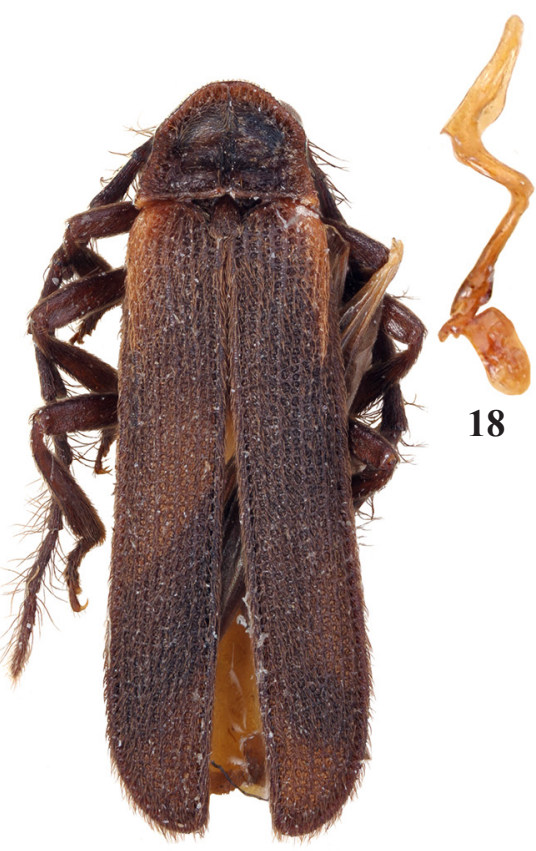

17

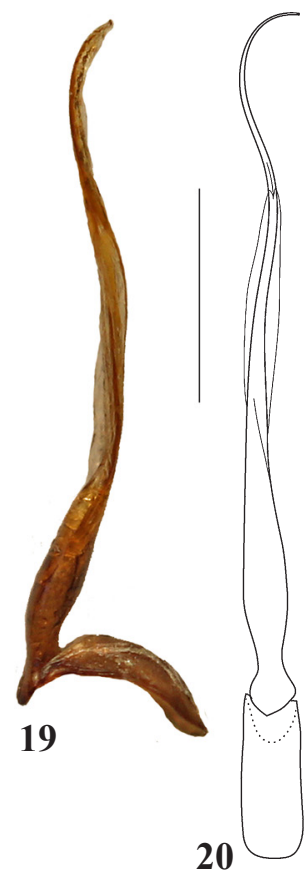

20

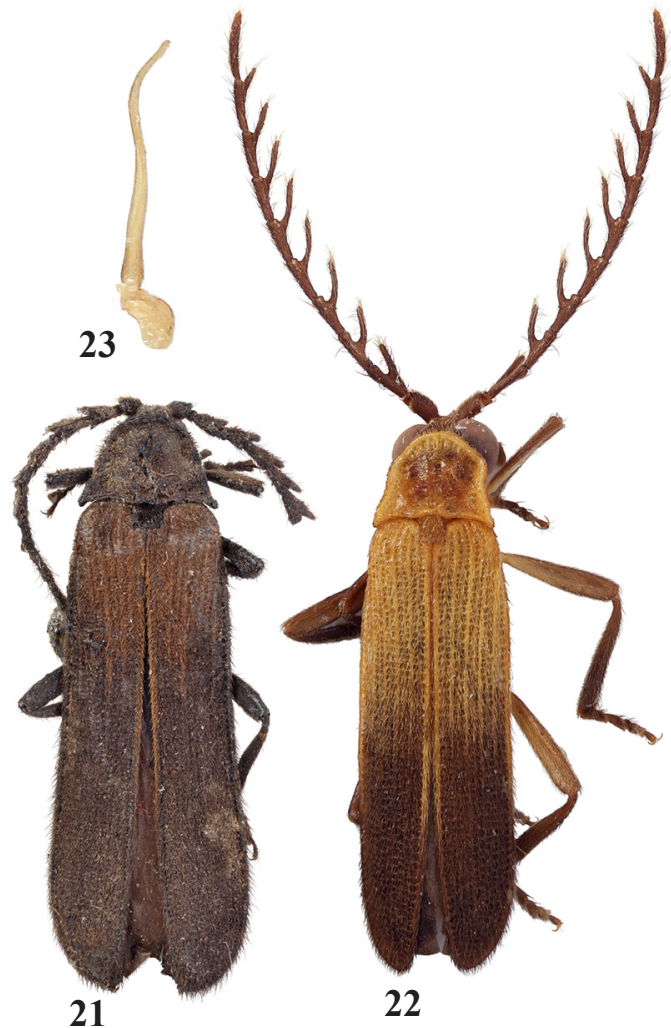

21

Figs 17-23. General view and aedeagus of Plateros spp., lectotypes: 17-18 - P. nigrosuturalis, 19-20-P. semang, 21 - P. sirambeus, 22-23 - P. suturellus; 17-29, 22-23 - males; 21 - female; 17, 21-22 - general view; 18-20, 23 - aedeagus; 17, 20-22 - dorsally; 18-19, 23 - laterally. Scale: $0.5 \mathrm{~mm}$.

Рис. 17-23. Общий вид и эдеагус Plateros, лектотипы: 17-18 - P. nigrosuturalis, 19-20 - P. semang, 21 - P. sirambeus, 22-23 P. suturellus; 17-29, 22-23 - самцы; 21 - самка; 17, 21-22 - общий вид; 18-20, 23 - эдеагус; 17, 20-22 - сверху; 18-19, 23 сбоку. Масштабная линейка: 0.5 мм. 
Aedeagus with straight and narrow median lobe, slightly widened and twisted distally (Fig. 25).

Female. Similar to male, but eyes smaller and antennae only serrate.

Length: 9.7-11.7 mm. Width (humerally): 2.1-2.9 mm.

ETYMOLOGY. The name of the new species is derived from the type locality.

DIAGNOSIS. Plateros alabensis sp.n. is readily distinguishable from all Plateros species by the black anterior part of body, including shoulders, and ochre elytra with black apices (Fig. 24), as well as by the shape of the aedeagus (Fig. 25).

\section{Plateros benomensis Kazantsev sp.n.} Figs 26-27

MATERIAL: Holotype, $\mathrm{O}^{7}$, W Malaysia, Pahang, Banjaran Benom Mts., 10-15 km SSE K. Ulu Dana, 17-23.IV.1997, D. Hauck leg. (ICCM); paratypes, $3 \mathrm{O}^{7} \mathrm{O}^{7}$, same label (ICCM).

DESCRIPTION. Male. Dark brown; pedicel and narrow pronotal anterior and lateral margins light brown.

Head dorsally with small conspicuous round impression behind antennal prominence, antennal sockets almost contiguous. Eyes moderately large (separated medially above by about their diameter). Ultimate maxillary palpomere longer than wide, widening distally, truncate at apex. Antennae from antennomere 3 flattened, slightly serrate, extending to elytral two thirds; antennomere 3 about 3 times longer than antennomere 2 and 1.1 times shorter than antennomere 4; antennomeres 3-11 with moderately long erect pubescence (Fig. 26).

Pronotum transverse, 1.4 times wider than long, with almost parallel sides, noticeable anterior and small acute posterior angles; anterior margin produced forward, slightly rounded, posterior margin bisinuate. Scutellum subquadrate, slightly emarginate at apex (Fig. 26).

Elytra moderately long (3.3 times as long as wide humerally), slightly widened distally, with equally developed primary costae, hardly distinguishable from secondary ones; interstices with irregular oval cells. Pubescence short and scarce (Fig. 26).
Aedeagus with short and robust median lobe, provided with several prominent distal dents (Fig. 27).

Female. Unknown.

Length: $4.9-5.8 \mathrm{~mm}$. Width (humerally): $1.2-1.5 \mathrm{~mm}$.

ETYMOLOGY. The name of the new species is derived from the type locality.

DIAGNOSIS. Plateros benomensis sp.n. may be distinguished from the similarly coloured Plateros species by the slightly serrate antennae and relatively short and robust median lobe of the aedeagus with several prominent distal dents (Figs 26-27).

\section{Plateros brinchangensis Kazantsev sp.n.} Figs 28-29

MATERIAL: Holotype, $0^{\top}$, W Malaysia, Pahang, Cameron Highlands, Brinchang Mt., 10.VI.1995, S. Kazantsev leg. (ICCM); paratypes: $ᄋ$, same label; + , W Malaysia, Cameron Highlands, Tanah Rata, MA3 G. Jasar, track 11, 1500 m, 16.XII.1996, Hendrich leg. (ICCM).

DESCRIPTION. Male. Dark brown; narrow pronotal anterior and lateral margins light brown.

Head dorsally with small deep round impression behind antennal prominence, antennal sockets almost contiguous. Eyes moderately large (separated medially above by about their diameter). Ultimate maxillary palpomere conspicuously longer than wide, widest in the middle, lanceolate at apex. Antennae from antennomere 3 flattened, slightly serrate, extending to elytral two thirds; antennomere 3 about 2.8 times longer than antennomere 2 and 1.2 times shorter than antennomere 4; antennomeres 3-11 with short erect pubescence and longer distal bristles (Fig. 28).

Pronotum transverse, 1.2 times wider than long, with parallel sides, obscure anterior and small posterior angles; anterior margin convex, posterior margin slightly bisinuate. Scutellum transverse, parallel-sided, rounded at apex (Fig. 28).

Elytra long and narrow (4.1 times as long as wide humerally), parallel-sided, with equally developed primary costae, hardly

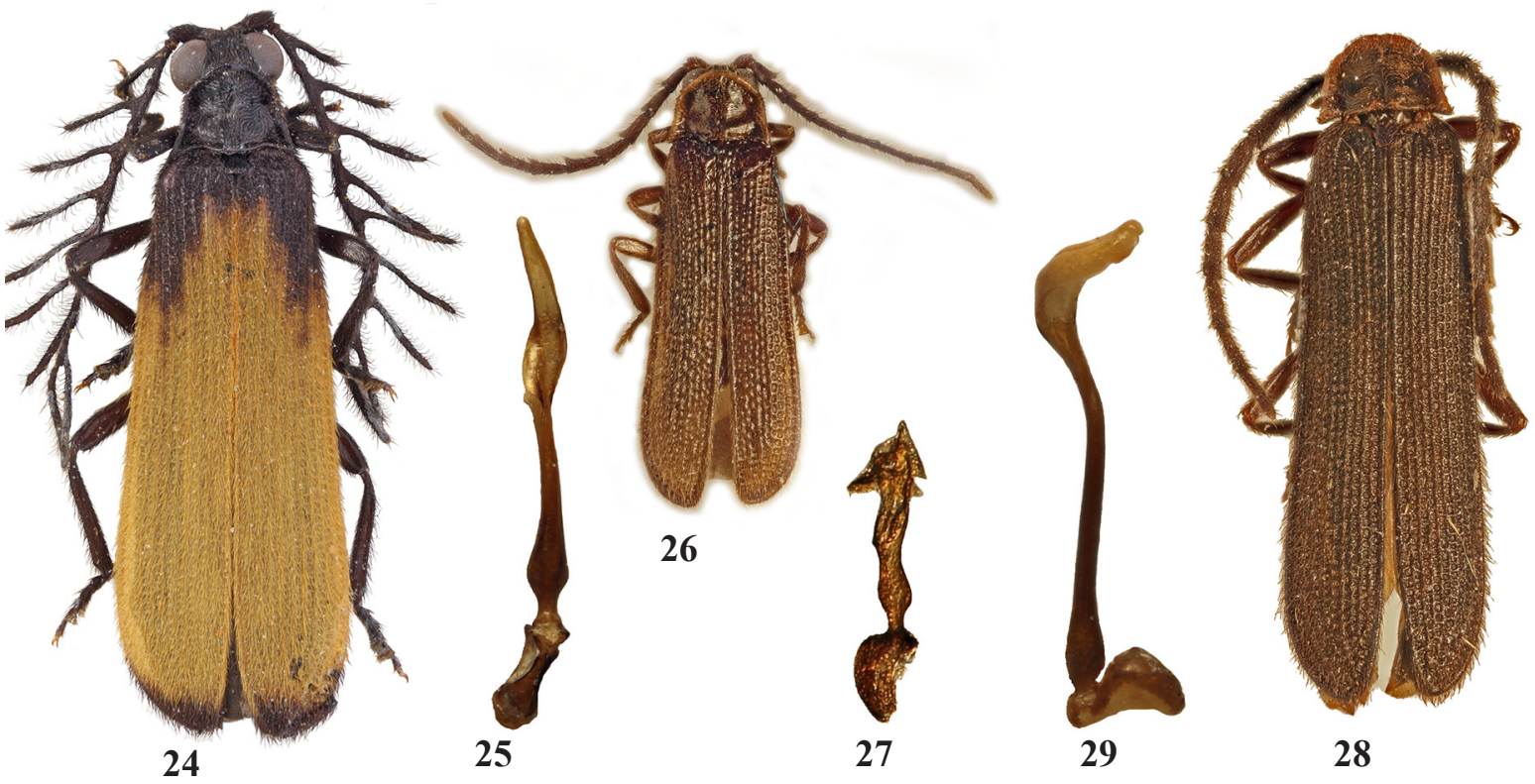

Figs 24-29. General view and aedeagi of Plateros spp., holotype males: 24-25 - P. alabensis sp.n.; 26-27 - P. benomensis sp.n., 2829 - P. brinchangensis sp.n.; 24, 26, 28 - general view; 25, 27, 29 - aedeagus.

Рис. 24-29. Общий вид и эдеагусы Plateros, голотипы, самцы: 24-25 - P. alabensis sp.n.; 26-27 - P. benomensis sp.n., 28-29 P. brinchangensis sp.n.; 24, 26, 28 - общий вид; 25, 27, 29 — эдеагус. 
distinguishable from secondary ones; interstices with regular subquadrate cells. Pubescence short and relatively dense (Fig. 28).

Aedeagus with long and narrow, distally widened and curved median lobe (Fig. 29).

Female. Similar to male, but eyes smaller and antennae serrate.

Length: 7.2-7.4 mm. Width (humerally): $1.5-1.8 \mathrm{~mm}$.

ETYMOLOGY. The name of the new species is derived from the type locality.

DIAGNOSIS. Plateros brinchangensis sp.n. may be distinguished from the similarly coloured congeners, e.g., $P$. benomensis sp.n., by the shorter antennal pubescence, long, parallel-sided elytra and long and narrow, distally widened and curved median lobe of the aedeagus (Figs 28-29).

\section{Plateros chechovskyi Kazantsev sp.n.}

Figs 30-31

MATERIAL: Holotype, OT, W Malaysia, W Kelantan, road btw Kampong Raja and Gua Masang (Ladang Pandrak), $4^{\circ} 63^{\prime} \mathrm{S} 101^{\circ} 45^{\prime} \mathrm{E} /$ $4^{\circ} 88^{\prime} \mathrm{S} 101^{\circ} 95^{\prime} \mathrm{E}, 1400-1700 \mathrm{~m}, 1-28 . I V .2006$, P. Chechovsky leg.(ICCM); paratype, $O^{7}$, same label (ICCM).

DESCRIPTION. Male. Uniformly dark brown to black.

Head dorsally with conspicuous round impression behind antennal prominence, antennal sockets almost contiguous. Eyes large (separated medially above by about 0.8 times their diameter). Ultimate maxillary palpomere considerably longer than wide, parallel-sided, flattened and obliquely truncate at apex. Antennae from antennomere 3 flattened, serrate, relatively short, extending to elytral three fifths; antennomere 3 about 2 times longer than antennomere 2 and 1.2 times shorter than antennomere 4; antennomeres 3-11 with short erect pubescence (Fig. 30).
Pronotum transverse, 1.2 times wider than long, with parallel sides, conspicuous anterior and small acute posterior angles; anterior margin noticeably produced forward, posterior margin bisinuate. Scutellum subquadrate, truncate at apex (Fig. 30).

Elytra long and narrow (4.1 times as long as wide humerally), parallel-sided, with equally developed primary costae, hardly distinguishable from secondary ones; interstices with small regular subquadrate cells. Pubescence short and relatively dense (Fig. 30).

Aedeagus with long, evenly curved median lobe, provided with helmet-like distal widening (Fig. 31).

Female. Unknown.

Length: $6.5-7.2 \mathrm{~mm}$. Width (humerally): $1.4-1.6 \mathrm{~mm}$.

ETYMOLOGY. The new species is named after the collector of its type series, Mr. P. Chechovsky.

DIAGNOSIS. Plateros chechovskyi sp.n. is separable from the similarly coloured congeners by the shape of the aedeagus with the long, evenly curved median lobe, provided with helmet-like distal widening (Fig. 31).

\section{Plateros frasericollis Kazantsev sp.n.} Figs 32-33

MATERIAL: Holotype, ơ, W Malaysia, Pahang, Fraser's Hill, 1000-1200 m, 28-30.I.1999, S. Kazantsev leg. (ICCM).

DESCRIPTION. Male. Uniformly black.

Head dorsally with deep elongate excavation behind antennal prominence, antennal sockets almost contiguous. Eyes relatively small (separated medially above by about 1.2 times their diameter). Ultimate maxillary palpomere elongate, inconspicuously widening distally, flattened and obliquely truncate at apex. Antennae from antennomere 3 flattened, strongly serrate, extending to elytral two thirds; anten-

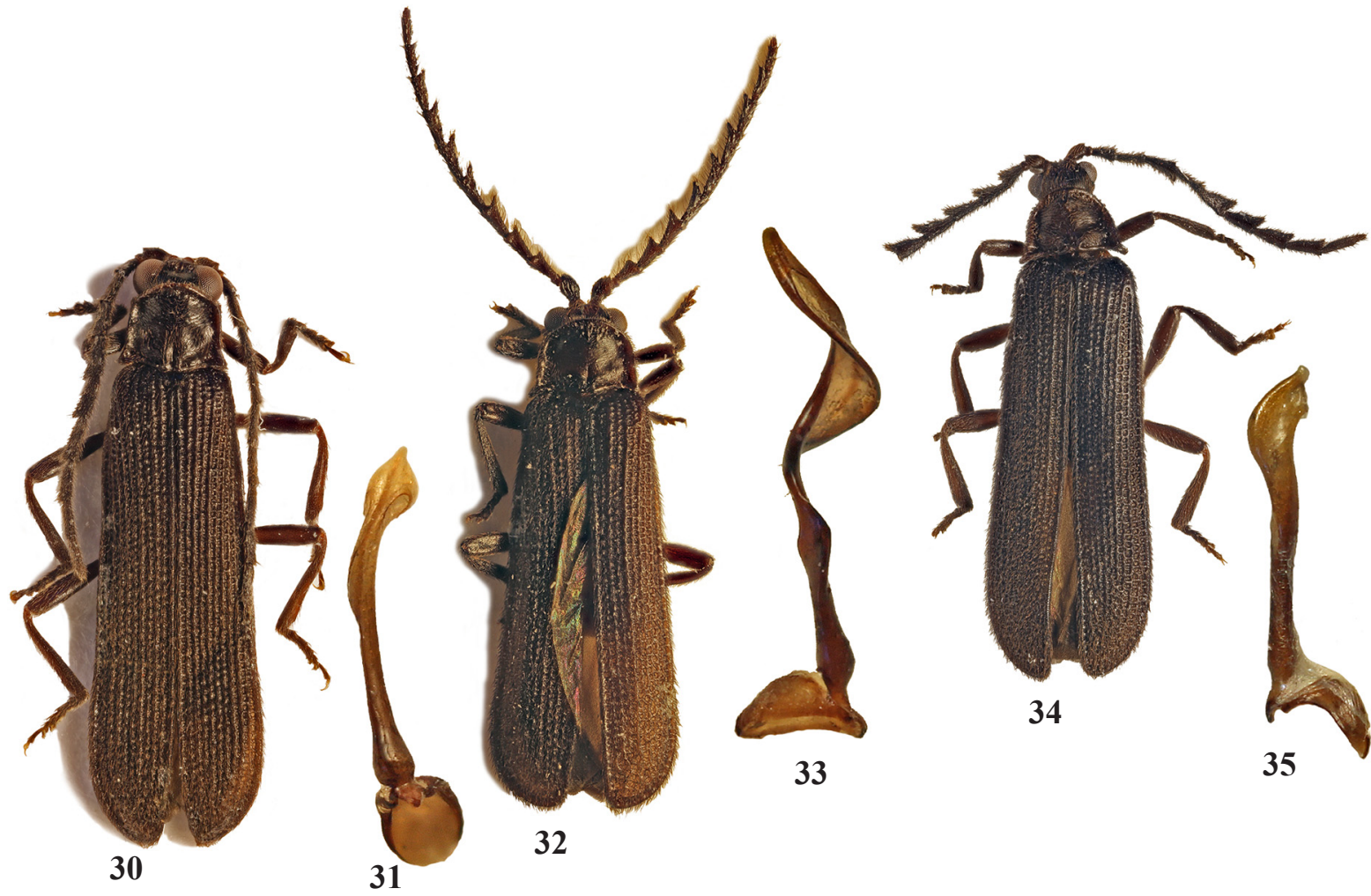

Figs 30-35. General view and aedeagi of Plateros spp., holotype males: 30-31 - P. chechovskyi sp.n.; 32-33 - P. frasericollis sp.n., 34-35 - P. guamasangensis sp.n.; 30, 32, $34-$ general view; 31, 33, 35 - aedeagus.

Рис. 30-35. Общий вид и эдеагусы Plateros, голотипы, самцы: 30-31 - P. chechovskyi sp.n.; 32-33 - P. frasericollis sp.n., 3435 - P. guamasangensis sp.n.; 30, 32, 34 - общий вид; 31, 33, 35 - эдеагус. 
nomere 3 about 2.2 times longer than antennomere 2 and subequal in length to antennomere 4; antennomeres 3-11 with long erect pubescence (Fig. 32).

Pronotum transverse, 1.3 times wider than long, with parallel sides, inconspicuous anterior and small acute posterior angles; anterior margin noticeably convex, posterior margin bisinuate. Scutellum transverse, parallel-sided, slightly emarginate at apex (Fig. 32).

Elytra long (3.4 times as long as wide humerally), parallelsided, with primary costae 1 and 2 more elevated than secondary costae in proximal half; interstices with regular subquadrate cells. Pubescence short and dense (Fig. 32).

Aedeagus with long twisted median lobe, conspicuously widened distally (Fig. 33).

Female. Unknown.

Length: $5.8 \mathrm{~mm}$. Width (humerally): $1.5 \mathrm{~mm}$.

ETYMOLOGY. The name of the new species is the Latin for "Fraser's Hill", alluding to the type locality.

DIAGNOSIS. Plateros frasericollis sp.n. is confidently separable from the similarly coloured congeners by the shape of the aedeagus with the long twisted median lobe, conspicuously widened distally (Fig. 33).

\section{Plateros guamasangensis Kazantsev sp.n.} Figs 34-35

MATERIAL: Holotype, O', W Malaysia, W Kelantan, road btw Kampong Raja and Gua Masang (Ladang Pandrak), $4^{\circ} 63^{\prime} \mathrm{S} 101^{\circ} 45^{\prime} \mathrm{E} /$ $4^{\circ} 88^{\prime} \mathrm{S} 101^{\circ} 95^{\prime} \mathrm{E}, 1400-1700 \mathrm{~m}, 1-28 . I V .2006$, P. Chechovsky leg.(ICCM); paratypes, 2 우 , same label (ICCM).

DESCRIPTION. Male. Uniformly black.
Head dorsally with transverse impression behind antennal prominence, antennal sockets noticeably separated. Eyes small (separated medially above by about 1.6 times their diameter). Ultimate maxillary palpomere elongate, inconspicuously widening distally, flattened and obliquely truncate at apex. Antennae from antennomere 3 flattened, strongly serrate, extending to elytral two thirds; antennomere 3 about 3 times longer than antennomere 2 and ca. 1.3 times shorter than antennomere 4; antennomeres 3-11 with short erect pubescence (Fig. 34).

Pronotum conspicuously transverse, 1.6 times wider than long, narrowing anteriorly, with small acute posterior angles; anterior margin semicircular, posterior margin bisinuate. Scutellum transverse, parallel-sided, slightly emarginate at apex (Fig. 34).

Elytra long (3.6 times as long as wide humerally), slightly widening distally, with primary costae stouter than secondary costae in proximal half; interstices with regular subquadrate cells. Pubescence short and dense (Fig. 34).

Aedeagus with relatively robust median lobe, semicircularly widened distally (Fig. 35).

Female. Similar to male, but larger, eyes smaller and antennae shorter and less serrate.

Length: $5.6 \mathrm{~mm}$ (male); 7.2-7.6 mm (female). Width (humerally): $1.3 \mathrm{~mm}$ (male); $1.7-1.75 \mathrm{~mm}$ (female).

ETYMOLOGY. The name of the new species is derived from the type locality.

DIAGNOSIS. Plateros guamasangensis sp.n. is distinguishable from the similarly coloured congeners by the shape of the aedeagus with the relatively robust median lobe, semicircularly widened distally (Fig. 35).

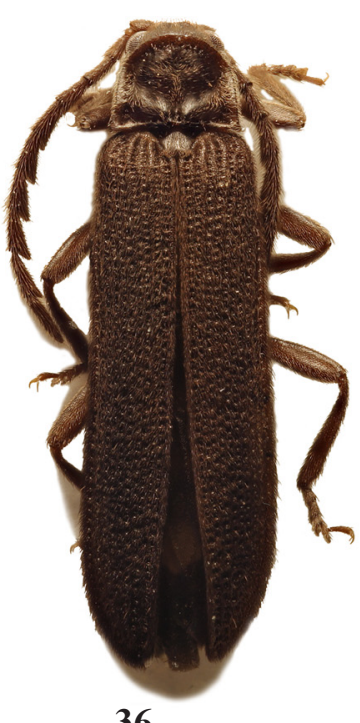

36
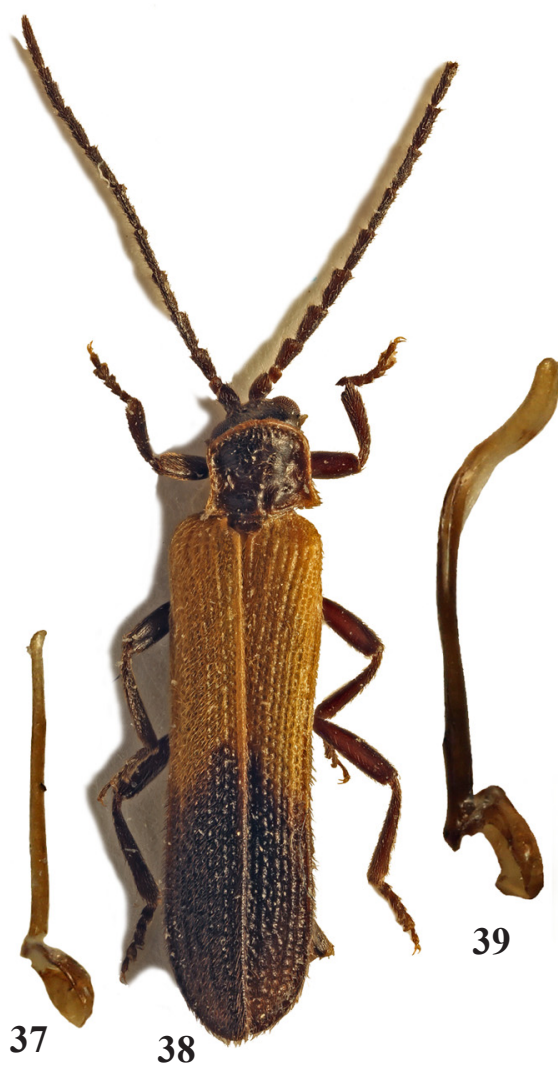

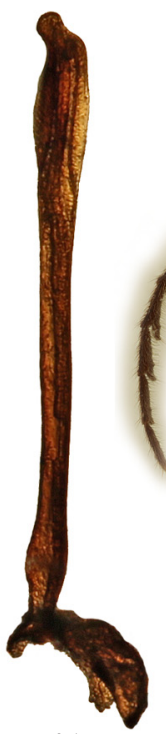

41

Figs 36-41. General view and aedeagi of Plateros spp., holotype males: 36-37 - P. hastatus sp.n.; 38-39 - P. khvylyai sp.n., 40-41 P. kurbatovorum sp.n.; 36, 38, 40 - general view; 37, 39, 41 - aedeagus.

Рис. 36-41. Общий вид и эдеагусы Plateros, голотипы, самцы: 36-37 - P. hastatus sp.n.; 38-39 - P. khvylyai sp.n., 40-41 - P. kurbatovorum sp.n.; 36, 38, 40 - общий вид; 37, 39, 41 - эдеагус. 


\section{Plateros hastatus Kazantsev sp.n.}

Figs 36-37

MATERIAL: Holotype, ऽ , W Malaysia, Pahang, Fraser's Hill, 1000-1200 m, 28-30.I.1999, S. Kazantsev leg. (ICCM).

DESCRIPTION. Male. Black; pedicel light brown.

Head dorsally with a pair of minute round impressions behind antennal prominence, antennal sockets separated by minute lamina. Eyes relatively small (separated medially above by about 1.2 times their diameter). Ultimate maxillary palpomere small, elongate, pointed and glabrous at apex. Antennae from antennomere 3 flattened, serrate, extending to elytral three fifths; antennomere 3 about 3 times longer than antennomere 2 and ca. 1.1 times shorter than antennomere 4; antennomeres 3-11 with short erect pubescence (Fig. 36).

Pronotum transverse, 1.3 times wider than long, slightly narrowing anteriorly, with rounded anterior and inconspicuous posterior angles; anterior margin semicircular, posterior margin almost uniformly concave. Scutellum transverse, trapezoidal, triangularly emarginate at apex (Fig. 36)

Elytra long (3.5 times as long as wide humerally), parallel-sided, with equally developed primary costae, hardly distinguishable from secondary ones; interstices with small subquadrate cells. Pubescence short and dense (Fig. 36).

Aedeagus with straight, narrow, with little modified apex median lobe (Fig. 37).

Female. Unknown.

Length: $5.0 \mathrm{~mm}$. Width (humerally): $1.15 \mathrm{~mm}$.

ETYMOLOGY. The name of the new species is derived from the Latin for "armed with a spear", alluding to the shape of its aedeagus

DIAGNOSIS. Plateros hastatus sp.n. differs from all known Plateros species in the shape of the ultimate maxillary palpomere, which is pointed and glabrous; additionally, it is distinguishable from black congeners by the shape of the aedeagus with the straight, narrow, little modified apically median lobe (Fig. 37)

\section{Plateros khvylyai Kazantsev sp.n.}

Figs 38-39

MATERIAL: Holotype, $\sigma^{7}$, Indonesia, Java, Mt. Gede, 1500 1600 m, 15-19.V.1997, S. Khvylya leg. (ICCM); paratypes, 2 우 same label (ICCM).

DESCRIPTION. Male. Dark brown; anterior and lateral pronotal margins and elytral proximal half (insignificantly extended along sides) testaceous.

Head dorsally with shallow longitudinal groove behind antennal prominence, antennal sockets nearly contiguous. Eyes small (separated medially above by about 1.3 times their diameter). Ultimate maxillary palpomere slightly longer than wide, widening distally, flattened and glabrous at apex. Antennae from antennomere 3 slightly flattened, almost filiform, extending to elytral three fifths; antennomere 3 about 3 times longer than antennomere 2 and ca. 1.2 times shorter than antennomere 4; antennomeres 3-11 with short erect pubescence (Fig. 38).

Pronotum nearly quadrate, only 1.15 times wider than long, with parallel sides, prominent anterior and small acute posterior angles; anterior margin convex, posterior margin bisinuate. Scutellum transverse, parallel-sided, slightly emarginate at apex (Fig. 38).

Elytra long (3.5 times as long as wide humerally), parallel-sided, with equally developed primary costae, hardly distinguishable from secondary ones; interstices with small oval cells. Pubescence short and dense (Fig. 38).
Aedeagus with narrow, conspicuously bent in distal half median lobe (Fig. 39).

Female. Similar to male, but somewhat larger and antennae filiform.

Length: 6.0-6.5 mm. Width (humerally): 1.4-1.6 mm.

ETYMOLOGY. The new species is named after Dr. Sergey Khvylya (Moscow), who collected the type series.

DIAGNOSIS. Plateros khvylyai sp.n. is distinguishable from the congeners by the combination of the upperside coloration (Fig. 38) and the shape of the aedeagus with narrow, conspicuously bent distally median lobe (Fig. 39).

\section{Plateros kurbatovorum Kazantsev sp.n. Figs 40-41}

MATERIAL: Holotype, $\sigma^{7}$, E Malaysia, Sabah, Mt. Kinabalu, 1600-1700 m, 16-30.VII.2002, S. Kurbatov \& S. Zimina leg. (ICCM); paratype, + E Malaysia, Prov. Sabah, Banjaran Crocker Mts., Gunung Alab peak, 1650-1800 m, 30.IV-27.V.1996, [M.] Strba [\& R. Hergovits] leg. (ICCM).

DESCRIPTION. Male. Black; pronotum, scutellum and elytra, except at apices, ochre.

Head dorsally with noticeable transverse impression behind antennal prominence, antennal sockets almost contiguous. Eyes large (separated medially above by about their diameter). Ultimate maxillary palpomere longer than wide, slightly widening distally, flattened and obliquely truncate at apex. Antennae from antennomere 3 flabellate, extending to elytral two thirds; flabellae moderately long and narrow, flabellum of antennomere 5 ca. 1.3 times longer than antennomere; antennomere 3 about 5 times longer than antennomere 2 and subequal in length to antennomere 4; pubescence relatively short, sparse and erect (Fig. 40).

Pronotum nearly quadrate, only 1.1 times wider than long, with parallel-sides, hardly noticeable anterior and acute posterior angles; anterior margin semicircular, posterior margin conspicuously bisinuate. Scutellum quadrate, truncate at apex (Fig. 40).

Elytra moderately long (3.2 times as long as wide humerally), parallel-sided, with primary costae 1-3 noticeably stouter than secondary costae; interstices with regular subquadrate cells. Pubescence short, dense and decumbent (Fig. 40).

Aedeagus with elongate and straight median lobe, slightly widened in distal fourth and constricted near apex (Fig. 41).

Female. Similar to male, but eyes smaller and antennae feebly dentate.

Length: 8.2-9.1 mm. Width (humerally): 2.0-2.2 mm.

ETYMOLOGY. The new species is named after Mr. and Ms. Kurbatov (Moscow), who collected one of the type specimens.

DIAGNOSIS. Plateros kurbatovorum sp.n. is somewhat similar to $P$. alabensis sp.n., distinguishable by the ochre pronotum, larger eyes, shorter antennal flabellae (Fig. 40) and different shape of the aedeagus with elongate and straight median lobe, slightly widened in distal fourth and constricted near apex (Fig. 41).

\section{Plateros lampungensis Kazantsev sp.n. Figs 42-43}

MATERIAL: Holotype, $\sigma^{7}$, S Sumatra, Lampung, Bukit Barisan Selatan N.P., 5 km SW Liwa, 600 m, 504'S 10404'E, 7-17.II.2000, D. Hauck leg. (ICCM); paratypes, $7 \sigma^{\top} \sigma^{\top}$, same label (ICCM).

DESCRIPTION. Male. Dark brown; pronotum, scutellum and elytra in proximal half orange testaceous.

Head dorsally with prominent round impression behind antennal prominence, antennal sockets nearly contiguous. Eyes large (separated medially above by about 0.6 times their diameter). Ultimate maxillary palpomere noticeably longer 
than wide, almost parallel-sided, obliquely truncate at apex. Antennae from antennomere 3 flabellate, extending to elytral two thirds; flabellae moderately long and broadly attached to antennomeres, flabellum of antennomere 5 ca. 1.3 times longer than antennomere; antennomere 3 about 4 times longer than antennomere 2 and subequal in length to antennomere 4; pubescence relatively short, sparse and erect (Fig. 42).

Pronotum conspicuously transverse, 1.6 times wider than long, trapezoidal, with prominent anterior and long acute posterior angles; anterior margin triangularly produced forward, posterior margin bisinuate. Scutellum quadrate, emarginate at apex (Fig. 42).

Elytra long (3.4 times as long as wide humerally), slightly widening distally, with primary costae $1-3$ noticeably stouter than secondary costae; interstices with regular subquadrate cells. Pubescence dense, short and decumbent (Fig. 42).

Aedeagus with straight, robust, abruptly widened in proximal third and twisted median piece, provided with dent and elongate lobes in distal half (Fig. 43).

Female. Unknown.

Length: 5.5-8.0 mm. Width (humerally): $1.3-2.0 \mathrm{~mm}$.

ETYMOLOGY. The name of the new species is derived from the province, where the type series was collected.

DIAGNOSIS. Plateros lampungensis sp.n. may be separated from similarly coloured congeners by the shape of the aedeagus with straight, robust, abruptly widened in proximal third, twisted and dentate median piece, provided with elongate lobes in distal half (Fig. 43).

\section{Plateros laruticollis Kazantsev sp.n.}

Figs 44-45

MATERIAL: Holotype, $\mathrm{O}^{7}$, W Malaysia, Perak, NE Taiping, Bukit Larut (Maxwell's Hill), 1100-1450 m, 7-9.II.1999, S. Kazantsev leg. (ICCM); paratypes, 2 +ㅇ, same label (ICCM).
DESCRIPTION. Male. Uniformly dark brown to black.

Head dorsally with prominent round impression behind antennal prominence, antennal sockets nearly contiguous. Eyes large (separated medially above by about 0.7 times their diameter). Ultimate maxillary palpomere noticeably longer than wide, slightly widening distally, obliquely truncate at apex. Antennae conspicuously tapering distally, extending to elytral two thirds, with antennomeres 3-5 noticeably widened and flattened; antennomere 3 about 4 times longer than antennomere 2 and ca. 1.2 times shorter than antennomere 4; pubescence relatively short, sparse and erect (Fig. 44).

Pronotum transverse, 1.2 times wider than long, with almost parallel sides, noticeable anterior and small acute posterior angles; anterior margin triangularly produced forward, posterior margin bisinuate. Scutellum transverse, trapezoidal, truncate at apex (Fig. 44).

Elytra long (3.4 times as long as wide humerally), slightly widening distally, with primary costae 1-3 somewhat stouter than secondary costae in proximal half; interstices with rectangular, mostly elongate cells. Pubescence dense, short and decumbent (Fig. 44).

Aedeagus with narrow, conspicuously bent in distal third and widened at apex median piece (Fig. 45).

Female. Similar to male, but eyes smaller.

Length: $6.8-7.1 \mathrm{~mm}$. Width (humerally): $1.5-1.6 \mathrm{~mm}$.

ETYMOLOGY. The name of the new species is the Latin for "Bukit Larut", alluding to the type locality.

DIAGNOSIS. Plateros laruticollis sp.n. may be separated from similarly coloured congeners by the shape of the aedeagus with narrow, conspicuously bent in distal third and widened at apex median piece (Fig. 45).

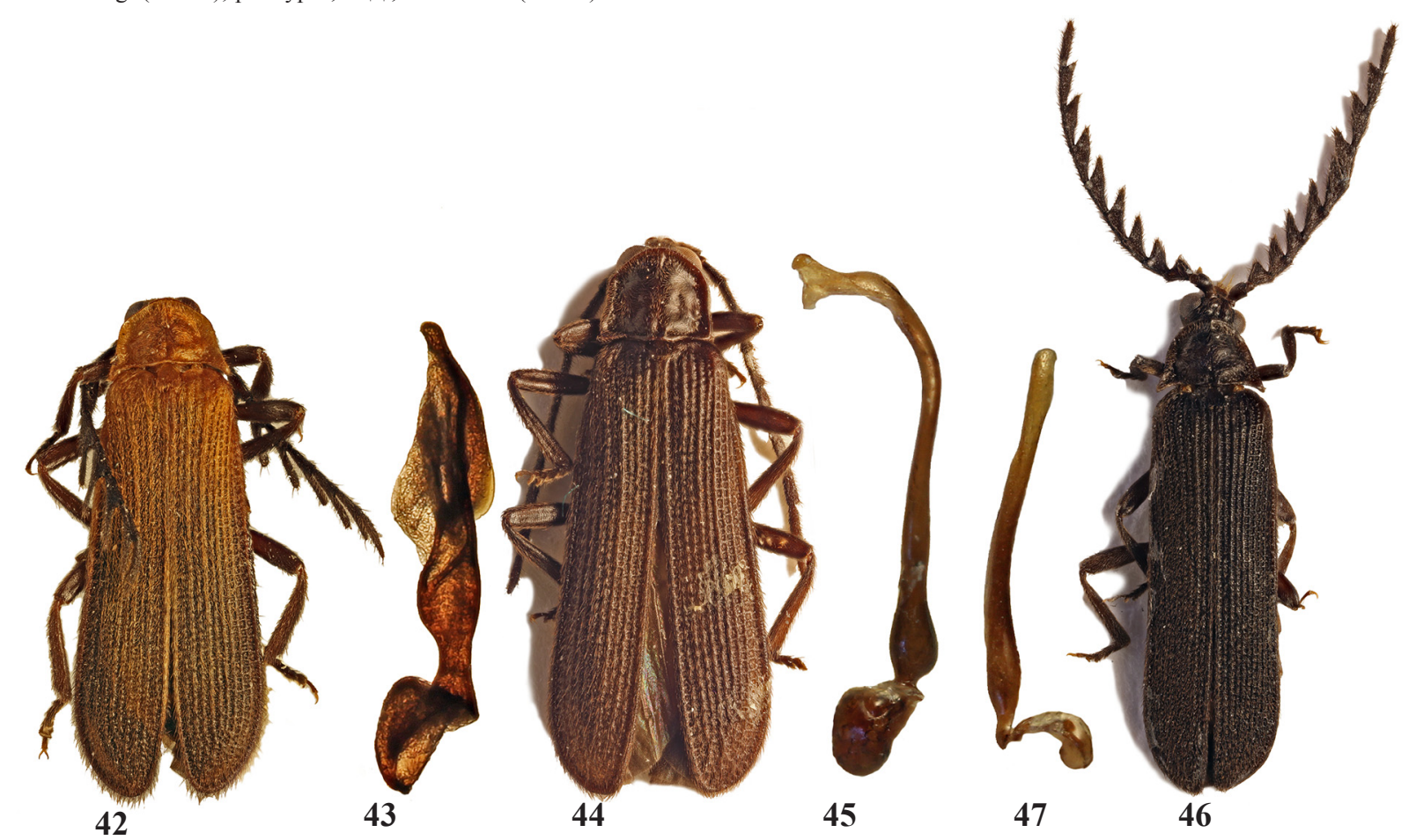

Figs 42-47. General view and aedeagi of Plateros spp., holotype males: 42-43 - P. lampungensis sp.n.; 44-45 - P. laruticollis sp.n., 46-47 - P. pandrakensis sp.n.; 42, 44, 46 - general view; 43, 45, 47 - aedeagus.

Рис. 42-47. Общий вид и эдеагусы Plateros, голотипы, самцы: 42-43 - P. lampungensis sp.n.; 44-45 - P. laruticollis sp.n., 4647 - P. pandrakensis sp.n.; 42, 44, 46 - общий вид; 43, 45, 47 - эдеагус. 


\section{Plateros pandrakensis Kazantsev sp.n.} Figs 46-47

MATERIAL: Holotype, $\sigma^{\top}$, W Malaysia, W Kelantan, road btw Kampong Raja and Gua Masang (Ladang Pandrak), $4^{\circ} 63^{\prime} \mathrm{S} 101^{\circ} 45^{\prime} \mathrm{E} /$ $4^{\circ} 88^{\prime} \mathrm{S} 101^{\circ} 95^{\prime} \mathrm{E}, 1400-1700 \mathrm{~m}, 1-28 . \mathrm{IV} .2006$, P. Chechovsky leg.(ICCM); paratypes, $2 \mathrm{O}^{\top} \mathrm{O}^{\top}$, same label (ICCM).

DESCRIPTION. Male. Uniformly dark brown to black.

Head dorsally with a pair of small longitudinal impressions behind antennal prominence, antennal sockets separated by narrow lamina. Eyes relatively small (separated medially above by about 1.2 times their diameter). Ultimate maxillary palpomere narrow, noticeably longer than wide, slightly widening distally, obliquely truncate at apex. Antennae strongly dentate, almost flabellate, extending to elytral two thirds; antennomere 3 about 2.2 times longer than antennomere 2 and ca. 1.2 times shorter than antennomere 4; pubescence relatively short, sparse and erect (Fig. 46).

Pronotum transverse, 1.4 times wider than long, narrowing anteriorly, with indistinguishable anterior and long acute posterior angles; anterior margin semicircularly produced forward, posterior margin bisinuate. Scutellum subquadrate, emarginate at apex (Fig. 46).

Elytra long and narrow (3.6 times as long as wide humerally), parallel-sided, with primary costae hardly distinguishable from secondary costae; interstices with small quadrate cells. Pubescence dense, short and decumbent (Fig. 46).

Aedeagus with narrow, slightly near middle median lobe (Fig. 47).

Female. Unknown.

Length: 5.4-6.8 mm. Width (humerally): $1.3-1.6 \mathrm{~mm}$.

ETYMOLOGY. The name of the new species is derived from the type locality.

DIAGNOSIS. Plateros pandrakensis sp.n. is readily distinguishable from $P$. curvicollis (Kleine, 1930), also with flabellate antennae, by the conspicuously shorter antennal flabellae (Fig. 46), as well as by the slenderer aedeagus (Fig. 47).

\section{Plateros riauensis Kazantsev sp.n. Figs 48-49}

MATERIAL: Holotype, $0^{7}$, E Sumatra, Riau, Bukit Tigapuloh N.P., $0^{\circ} 50^{\prime} \mathrm{S} 102^{\circ} 26^{\prime} \mathrm{E}, 18-25 . \mathrm{I} .2000$, D. Hauck leg. (ICCM); paratypes, $2 O^{7} O^{2}$ and 2 O $P$, same label (ICCM).

DESCRIPTION. Male. Dark brown to black; pronotal margins narrowly light brown.

Head dorsally with a pair of small roundish impressions behind antennal prominence, antennal sockets contiguous. Eyes large (separated medially above by about 0.6 times their diameter). Ultimate maxillary palpomere noticeably longer than wide, parallel-sided, obliquely truncate at apex. Antennae from antennomere 3 flabellate, extending to elytral two thirds; flabellae moderately long and narrow, flabellum of antennomere $5 \mathrm{ca} .1 .4$ times longer than antennomere; antennomere 3 about 3 times longer than antennomere 2 and subequal in length to antennomere 4; pubescence relatively short, sparse and erect (Fig. 48).

Pronotum transverse, 1.4 times wider than long, slightly narrowing anteriorly, with conspicuous anterior and posteriorly produced acute posterior angles; anterior margin prominently produced forward, posterior margin almost straight. Scutellum quadrate, truncate at apex (Fig. 48).

Elytra moderately long ( 3.2 times as long as wide humerally), parallel-sided, with primary costa 2 noticeably stouter than other primary costae in proximal two thirds; interstices with subquadrate roundish cells. Pubescence dense, short and decumbent (Fig. 48).

Aedeagus with robust constricted above middle median piece, bifid at apex and provided with prominent dent (Fig. 49).

Female. Similar to male, but eyes smaller and antennal flabellae shorter.

Length: $5.3-6.6 \mathrm{~mm}$. Width (humerally): $1.4-1.6 \mathrm{~mm}$.

ETYMOLOGY. The name of the new species is derived from the province, where the type series was collected.

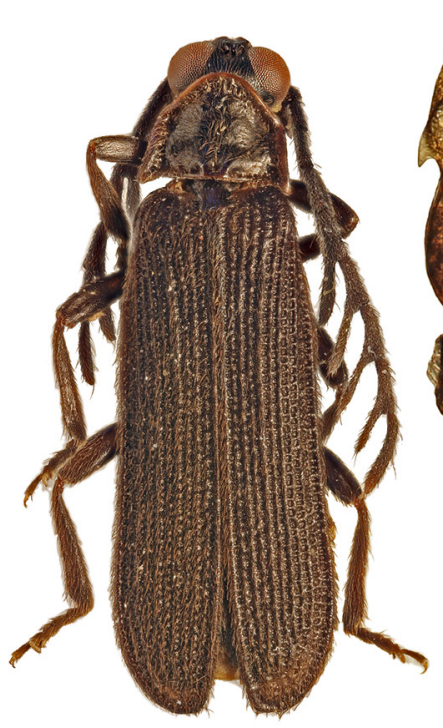

48

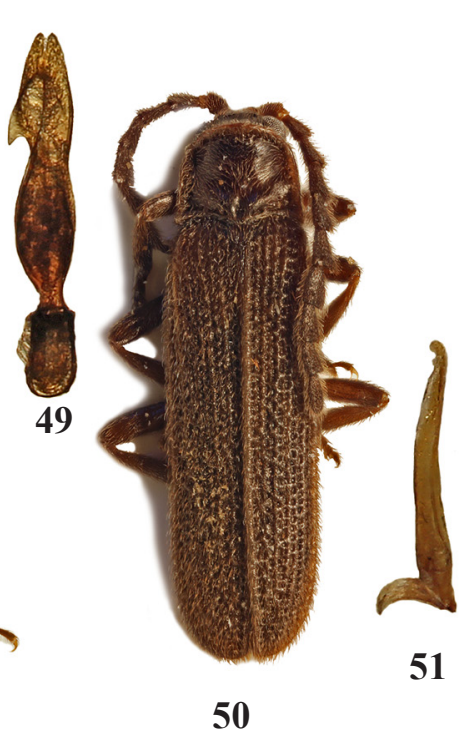

50

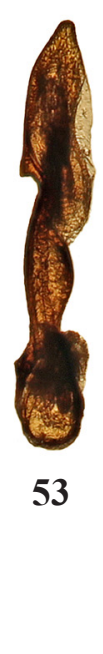

53

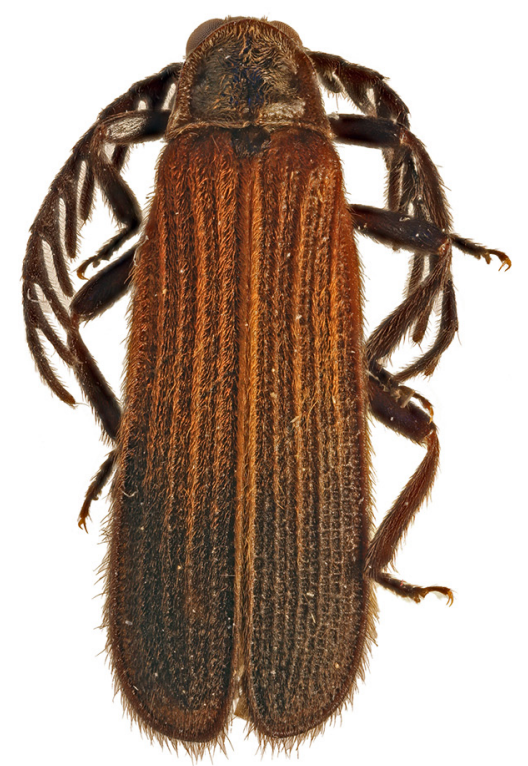

52

Figs 48-53. General view and aedeagi of Plateros spp., holotype males: 48-49-P. riauensis sp.n.; 50-51 - P. selendangensis sp.n., 52-53 - P. sundaensis sp.n.; 48, 50, 52 — general view; 49, 51, 53 - aedeagus.

Рис. 48-53. Общий вид и эдеагусы Plateros, голотипы, самцы: 42-43 - P. lampungensis sp.n.; 44-45 — P. laruticollis sp.n., 4647 - P. pandrakensis sp.n.; 48, 50, 52 - общий вид; 49, 51, 53 - эдеагус. 
DIAGNOSIS. Plateros riauensis sp.n. may be separated from similarly coloured congeners by a combination of flabellate antennae and robust, constricted above middle median piece of the aedeagus, bifid at apex and provided with prominent dent (Fig. 49).

\section{Plateros selendangensis Kazantsev sp.n.} Figs 50-51

MATERIAL: Holotype, $\mathrm{O}^{\top}, \mathrm{W}$ Malaysia, Pahang/Johor, EndauRompin N.P., Selendang, 100 m, 28.II-12.III..1995, M. Strba \& R. Hergovits leg. (ICCM).

DESCRIPTION. Male. Uniformly dark brown to black.

Head dorsally with round impression behind antennal prominence, antennal sockets separated by relatively broad lamina. Eyes small (separated medially above by about 1.5 times their diameter). Ultimate maxillary palpomere narrow, noticeably longer than wide, pointed and glabrous at apex. Antennae dentate, slightly reaching over elytral middle; antennomere 3 about 3 times longer than antennomere 2 and ca. 1.2 times shorter than antennomere 4; pubescence relatively short, sparse and erect (Fig. 50).

Pronotum transverse, 1.2 times wider than long, with almost straight sides, inconspicuous anterior and short acute posterior angles; anterior margin convex, posterior margin bisinuate. Scutellum elongate, parallel-sided, rounded at apex (Fig. 50).

Elytra long (3.2 times as long as wide humerally), parallel-sided, with primary costae hardly distinguishable from secondary costae; interstices with irregular roundish cells. Pubescence dense, short and decumbent (Fig. 50).

Aedeagus with straight, relative narrow and tapering distally median lobe (Fig. 51).

Female. Unknown.

Length: $3.9 \mathrm{~mm}$. Width (humerally): $1.0 \mathrm{~mm}$.

ETYMOLOGY. The name of the new species is derived from the type locality.

DIAGNOSIS. Plateros selendangensis sp.n. is readily distinguishable from similarly coloured congeners by the combination of pointed ultimate maxillary palpomere, dentate antennae and straight, relatively narrow and tapering distally median piece of the aedeagus (Fig. 51)

\section{Plateros sundaensis Kazantsev sp.n. Figs 52-53}

MATERIAL: Holotype, $\sigma^{7}$, E Sumatra, Riau, Bukit Tigapuloh N.P., $0^{\circ} 50^{\prime} \mathrm{S} 102^{\circ} 26^{\prime} \mathrm{E}, 18-25 . \mathrm{I} .2000$, D. Hauck leg. (ICCM); paratypes, 2 앙, same label (ICCM).

DESCRIPTION. Male. Dark brown; elytral proximal two thirds reddish testaceous.

Head dorsally with a pair of small longitudinal impressions behind antennal prominence, antennal sockets nearly contiguous. Eyes large (separated medially above by about 0.7 times their diameter). Ultimate maxillary palpomere small, slightly longer than wide, widest proximally, obliquely truncate and rounded at apex. Antennae from antennomere 3 flabellate, extending to elytral two thirds; flabellae moderately long and broadly attached to antennomeres, flabellum of antennomere $5 \mathrm{ca} .1 .4$ times longer than antennomere; antennomere 3 about 4 times longer than antennomere 2 and subequal in length to antennomere 4 ; pubescence relatively short, sparse and erect (Fig. 52).

Pronotum transverse, 1.5 times wider than long, trapezoidal, with noticeable anterior and moderately long acute posterior angles; anterior margin triangularly produced forward, posterior margin bisinuate. Scutellum transverse, truncate at apex (Fig. 52).

Elytra long (3.4 times as long as wide humerally), slightly widening distally, with primary costae noticeably stouter than secondary costae; interstices with regular subquadrate cells. Pubescence dense, short and decumbent (Fig. 52).

Aedeagus with robust, constricted, twisted at middle and dentate median piece (Fig. 53).

Female. Similar to male, but eyes smaller and antennae just strongly serrate.

Length: $8.0-10.6 \mathrm{~mm}$. Width (humerally): $2.0-2.7 \mathrm{~mm}$.

ETYMOLOGY. The name of the new species is derived from the region, where the type series was collected.

DIAGNOSIS. Plateros sundaensis sp.n. is distinguishable from similarly coloured congeners by the robust, constricted at middle and dentate median piece of the aedeagus (Fig. 53).

Plateros irregularis (Pic, 1921)

Ditoneces irregularis Pic, 1921: 4

Ditoneces soror Kleine, 1930: 170, syn.n.

MATERIAL: Lectotype, hereby designated, $\sigma^{7}$, [Sumatra], "Bosehres Bandas, 12.II.1920, J.B. Corporaal" [Corporaal's manuscript label], "No. 6", "D. irregularis n.sp." [Pic's manuscript labels] (MNHN); O', Malaysia, Ulu Gombak, Kuala Lumpur, 28.VIII.1981, R.E. Parrot (ICCM).

REMARKS. As Pic's [1921] description does not indicate the uniqueness of the specimen, the lectotype of Ditoneces irregularis Pic, 1921 is hereby designated in compliance with the ICZN to clarify the application of the name to a taxon. Comparison of the description of D. soror (from «Perak», Peninsular Malaysia), which includes an illustration of the aedeagus, with the lectotype of $P$. irregularis (from «Bosehres Bandas», Sumatra) demonstrates that the two taxa belong to a single species. Hence, Ditoneces soror Kleine, 1930, syn.n. becomes a new synonym of Plateros irregularis (Pic, 1921).

\section{Plateros vetustus Kleine, 1932}

Plateros vetustus Kleine, 1932: 123

Plateros nigricolor Pic, 1943: 14, syn.n., also homonym [nec Plateros nigricolor (Pic, 1932)]

Plateros pullatus Kazantsev, 2011: 186 (RN), syn.n.

MATERIAL: Lectotype, hereby designated, $\sigma^{7}$, [Malaysia], "Malacca", "Plateros nigricolor sp.n." [Pic's manuscript labels] $(\mathrm{MNHN}) ; \sigma^{7}$ and $\$$, W Malaysia, Pahang, Cameron Highlands, env. Tanah Rata, 2-9.IV.1997, D. Hauck leg.; $\sigma^{7}$ and 9 , W Malaysia, W Kelantan, road btw Kampong Raja and Gua Masang (Ladang Pandrak), 4 ${ }^{\circ} 63^{\prime} \mathrm{S} 101^{\circ} 45^{\prime} \mathrm{E} / 4^{\circ} 88^{\prime} \mathrm{S} 101^{\circ} 95^{\prime} \mathrm{E}, 1400-1700 \mathrm{~m}, 1-$ 28.IV.2006, P. Chechovsky leg. (ICCM).

REMARKS. As Pic's [1943] description does not indicate the uniqueness of the specimen, the lectotype of Plateros nigricolor Pic, 1943 is hereby designated in compliance with the ICZN to clarify the application of the name to a taxon. Comparison of the lectotype of $P$. nigricolor Pic, 1943 (from «Malacca»), with the description of $P$. vetustus (from «Perak: Larut Hills»), which includes an illustration of the aedeagus, demonstrates that the two taxa belong to a single species. Hence, Plateros nigricolor Pic, 1943, syn.n. becomes a new synonym of Plateros vetustus Kleine, 1932. Consequently, the replacement name Plateros pullatus Kazantsev, 2011, syn.n., which was introduced to replace Plateros nigricolor Pic, 1943 [nec Plateros nigricolor (Pic, 1932), from Bolivia], also becomes a junior synonym of $P$. vetustus.

ACKNOWLEDGEMENTS. I wish to express my gratitude to Dr. J. Menier (Muséum national d'Histoire naturelle, Paris), through whose courtesy I was able to study the Lycidae collections under his care. My sincere thanks are due to Dr. O. Gorbunov (Moscow), Dr. S. Khvylya (Moscow) and Dr. S. Kurbatov (Moscow) for donation of the interesting oriental lycid material. I am also grateful to Prof. K.V. Makarov (Moscow) for the help with the colour photos. 


\section{References}

Bocáková M. 1997a. Revision of the genus Melaneros from China with a note on Ditoneces (Coleoptera, Lycidae) // Acta Soc. Zool. Bohem. Vol.61. P.175-190.

Bocáková M. 1997b. Revision and phylogenetic analysis of the genus Melaneros Fairmaire, 1877 (Coleoptera, Lycidae) from New Guinea // Entom. Basil. Vol.20. P.165-222.

Kazantsev S.V. 1991. To the knowledge of oriental Lycidae (Coleoptera). Remarks on Lycidae of Himalaya // Entom. Basil. B.14. P.153-182.

Kazantsev S.V. 1992. To the knowledge of oriental Lycidae (Coleoptera). III. Notes on Plateros Bourgeois and Ditoneces C.O. Waterhouse // Russ. Entom. J. Vol.1. No.2. P. 29-31.

Kazantsev S.V. 1997. Sur le sous-genre Planeteros (Coleoptera, Lycidae) // Rev. fr. d'Entom. (N.S.). Vol.19. Nos.1-2. P.7-17.

Kazantsev S.V. 2000. To the knowledge of the African subgenus Planeteros of the genus Melaneros (Coleoptera, Lycidae) // Beitr. Ent. B.5. H.1. S.103-118.
Kazantsev S.V. 2001. New species of the genus Melaneros Fairmaire, 1879 from Nepal, China and the USA (Coleoptera, Lycidae) // Russ. Entom. J. Vol.10. No.1. P.13-16.

Kazantsev S.V. 2005. Contribution to the knowledge of the genus Plateros Bourgeois, 1879 (Lycidae, Coleoptera) // Russ. Entom. J. Vol.13. No.4 (2004). P.237-244.

Kazantsev S.V. 2011. New and little known taxa of Platerotini, with a note on biogeography of the tribe (Lycidae, Coleoptera) // Russ. Entom. J. Vol.20. No.2. P.151-158.

Pic M. 1921-1922. Contribution à l'étude des Lycides // L'Echange, hors texte. Vol.37-38. Nos.404-410. P.1-28.

Pic M. 1924-1939. Malacodermes exotiques // L'Echange, hors texte. Vol.40-55. Nos.418-477. P.1-472.

Pic M. 1943. Coléoptères du Globe // L'Echange. Vol.59. P. 5-7, 13-14.

Zaragoza Cabaliero S. 1999. Cantharoidea (Coleoptera) de Mexico. III. El genero Plateros Bourgeois (Lycidae: Erotinae: Platerodini) // Acta Zool. Mex. (n.s.). Vol.78. P.1-71. 